\title{
Roxana Patraș
}

\section{When All That Rests Is Literature: Traces, Transcriptions and Remnants of Great Speeches}

\begin{abstract}
Barbu (Ștefănescu) Delavrancea's public career (around 1880-1918) is marked not only by the tragic predicament of literary verbosity, but also by a sense of dissolution implied in the very nature of the art of eloquence. Being endowed with a Byronic nature, the Romanian writer experiences the irreducible tension between spoken and written words, and tends to solve it by assuming a pseudonym, a fake identity. The present essay shows that, in Delavrancea's case, the unsteady identity of the orator corresponding to "the name issue" tackled in his early political speeches and to the reduplication of pseudonyms in his youth literature - leads to a reduplication of texts (recycled and rewritten versions coexist with the originals) and to paradoxical political attitudes (the embodiment of consciousness explains moral shortcomings).
\end{abstract}

Keywords: Byron; Pathos; Emulation; Pseudonym; Energy; Entropy; Number; Party; People; Imagines Agentes.

\section{ROXANA PATRAș \\ "Alexandru loan Cuza" University of Iași, Romania roxana.patras@yahoo.ro}

DOI: 10.24193/cechinox.2017.33.15

\section{Transcribing the Sensorium of Byronic Heroes.} Erasure and Admiration

$\mathrm{I}$ $\mathrm{t}$ is reported that some of the nineteenth-century great writers would have given all their literary awards for a moment of triumph in war. Their obsession with eloquence has been already discussed, especially in the frame of the heroic cult nurtured by Napoleon and the Napoleonic wars. Even though there is no apparent determination between them, ancient rhetoricians such as Tacitus and $\mathrm{Cicero}^{1}$ point out that the art of fine speaking appeared in the aftermath of the Peloponnesian wars, as a result of the society's indulging in effeminate luxury and moral decay. In fact, Quintilian considers that attack and defense are the archetypal impulses of ars bene dicendi; thus, analogies such as rhetoric-sword, orator-soldier or polemic-battle/war do not seem so far-fetched for him. ${ }^{2}$ Turning to the Homeric epic, we can discover that whenever the siege of Troy was ceasing, Ulysses and Nestor used to engage themselves in eloquence competitions, ${ }^{3}$ as 
if crossing words served for flaring up their martial disposition and for preparing the forthcoming battles. In times of peace or during war interludes, eloquence transferred the military spirit within the realm of words and might have functioned as a substitute of war.

Taking into consideration biographical facts, such "substitution" (eloquence-war) might be valid for all romantic writers. For instance, David Francis Taylor emphasizes Byron's oratorical ambitions, which develop not only from his confidence that oratory has a greater political, civic and military efficiency than any form of art, but also from his belief that eloquence can serve as a mediator in the irreducible conflict between speaking and writing. ${ }^{4}$ Yet, Byron seems to have been aware that, compared to the materiality of printed literature and to its promises of immortality, the glory derived from oratorical careers also contains a sense of evanescence and disarticulation.

Childe Harold's Pilgrimage was composed when Byron, helped by Richard Brinsley Sheridan, was preparing himself to become an orator of the English Parliament. His other poems contain so many isles of pure declamation that one might suspect them as being actual training sessions in view of a prospective political career. Byron's master - a playwright and a great orator himself - is said to have been particularly resistant to the procedures of his speeches' textualization. Scholars traced here the influence of Sheridan's own father, who wrote at length on elocution and emphasized - against Locke's ideas on human understanding - the contrast between embodied speech ${ }^{5}$ and writing, between what the language of emotions and the language of ideas can accomplish. The point of both Sheridans seems to be the following: when speeches are jotted down or reported (by witnesses or registrars), the arbitrariness of written words corrupts their unfailing greatness.

Transcription and witnessing - externalization in general - heap upon speeches a corruptive and burdening historical dimension. As Christopher Reid puts it, the "extra-parliamentary dimension" of speech deliveries generates an "uneasy relationship between event and report."

However, this does not happen only on grounds of the radical conflict between speaking and writing, but also in terms of the original-duplicate relationship. Consequently, what is outside the speech's aura ${ }^{7}$ be it transcription, testimony, even literature - represents a mere copy of the moment of delivery, its sham-life. It is not by chance that William Hazlitt notices the following: "the most dashing orator I ever heard is the flattest writer I ever read. In speaking, he is like a volcano vomiting out lava; in writing, he is like a volcano burnt out."

How did Byron get out of this aporia? It seems that eventually Byron chose literature because he "found in the literary text a greater degree of liberty, formally and politically, than parliamentary oratory could allow." But did he have any nostalgia regarding his relinquished political career? Apparently, he did. Byron's diary outlines several portraits of great speakers and thus problematizes the cultural transmission of oratory, its "unstable afterlife." Apparently, he must have understood that the memory of famous orations can only be approached through "multiple layers of remediation." ${ }^{10}$

Life's original sparkle, that is, the aura of speech seems to be always condemned not 
only to evanescence, but also to collapsing under its own recollections, under its textual approximations and perhaps adjoining literature. In this point of discussion, the image of abundant failures piling up Life is the one that intimidates the most.

\section{ø}

Barbu Ștefănescu Delavrancea (18581918) is, according to Tudor Vianu, "the last Byronic author of the world's literature." ${ }^{11}$ Due to his intense "exposure" both as a columnist and as lead voice of the Liberal Party, he was entitled to play a VIP part among his fellow writers quite early, from his debut in $1880 .{ }^{12}$ His great potential accommodated him in the posture of "a nonchalant waster."13 All testimonies emphasize on his visual acuteness as well as on his several other talents: drawing and painting, architecture and music, art and theatre criticism, literature, oratory and law. Yet, in spite of this unmistakable Byronic air, literary histories approach his works in a wholesale manner by referring Delavrancea to the "post-Eminescu school,"14 to the "literature around $1900 " 15$ or to "the end of the (nineteenth) century."16

Taking after their author, a significant number of Delavrancea's characters bear the features of Byron's Manfred or Childe Harold: the heart's obduracy, the enigmatic depth of silence, the fierce melancholy, a dark sense of fatality and perhaps self-denied kindness. Tudor Vianu assumes that the writer must have perceived the perils enclosed in this aesthetics, chiefly in the propulsion for furious declamation. Hence, says the critic, the entire "evolution" of Delavrancea's writing is marred by a troubling concern with taking himself out of this predicament. Vianu also believes that, by turning to theatre at the end of his career, the writer actually found a way out of this trap. Being equally fascinated by Delavrancea's political oratory, the Romanian critic credits the speaker's success to his way of interfusing with the masses, of catching the currents of sensibility running throughout, and, last but not least, to his way of lending the masses his own voice, body and even (pseudo)name. The fascination for both the speaker's magic and his speech's aura will be thus a common note of all the following criticism devoted to Delavrancea's oratory.

Reacting in the same fashion to Delavrancea's stimuli, Titu Maiorescu who was the polemist's first victim in the 1894 session of Lower Chamber of the Romanian Parliament - expresses the huge admiration for his former political adversary. Indeed, admits Maiorescu, he is "the most brilliant orator of contemporary Romania." ${ }^{17}$ The leader of the Junimea Circle caught perfectly Delavrancea's phenomenal, passionate and vehement way of phrasing things: ${ }^{18}$

This time too Delavrancea was the phenomenal orator, with an unprecedented force to electrify a popular audience and to shake it to the marrow. What marvels me is his aptness to produce the same effect even when he does not use the common clichés of oratory, but specialized terms from modern sciences such as sociology, law, philosophy, even physiology [emphasis added]. ${ }^{19}$

Many others bear testimony that, around 1909, Delavrancea used to lecture 
before extremely crammed amphitheaters that listened to him "in deep, religious silence." During these lectures, young admirers chided the noisy newcomers: "Hush! Delavrancea is speaking!." At the beerhouse "Gambrinus," people already accustomed to his phenomenal oratory were still spellbound by Delavrancea's innate histrionic talent when he declaimed Iliada and Toma Alimos or when he read expressively Stephen the Great's speeches from Moldova's trilogy. ${ }^{20}$

Showing little interest in the mechanisms of invention, disposition, elocution, action, and memory, neither witnesses nor commentators could manage to get beyond a certain level of interjectional admiration and servile paraphrasing of contents. ${ }^{21}$ Nevertheless, their helplessness in front of Delavrancea's magic should be considered a symptom of erasure. More specifically, failing to develop "an aesthetic conduct of attention," ${ }^{22}$ this mystical admiration ends by erasing the admiration's object. An erasure that is not effected through passive forms of exclusion (lack of affinity, negligence, non-focus, incuriosity, indifference) or through obliteration attitudes (destruction, ignorance or refusal), but through a well-meaning attention that, by trying to approximate the dimming signal of lost Life, ends in producing waste. The same is valid not only for audiences, but also for the orator himself, especially when he relates to his former performances and attempts at jotting them on paper.

While it is not the speech but its aura that gets lost in the process of cultural transfer, one can legitimately ask whether this loss is "radical" or "imperfect." 23 In epistemic terms, the loss appears to be radical since eloquence derives from one's opinion, thus from something that has no absolute certainty. In sensorial terms instead, the loss seems to be imperfect as long as its leaves a perceptible trace that can be reconstructed in the realm of attention maintained by interconnected senses. Both external senses (sight, hearing, touch, taste, smell) and internal senses (pain, hunger, thirst, sexual drive) can help us to get closer to the speech's aura. Their connectedness is an indicator of the speech's potential discharge of energy; also, it is an indicator of the speech's potential in producing Afterlife copies, thus for leaving behind waste, leftovers. The intensity of living can be indicated through the waste that Life yields, through the quantity of literature that the moment of glory outturns. As a matter of fact, the rhetoricians' late interest for what Marshall McLuhan has called "sensorium" ${ }^{24}$ opens a way to what might be the best method for accessing the blanked pages of the orators' momentous glory.

\section{Recovering the Moment of Glory and Fighting Back Entropy}

Turning to Delavrancea's presumptive 1 Byronic character, one cannot refrain from asking how the Romanian author got out of the aforementioned aporias speaking-writing, event-report, original-copies. No matter how great the pleasure derived from the crowds' applauses, from being on pole position or from sheer awareness of his own natural gifts, Delavrancea must have sensed this paradox. Long before he became a politician (1894), he had found out that he was preaching social reformation during an age of decadence, characterized by ideological dissolution and aesthetic diffusion. On the one hand, we can see a 
Byronic prodigy that wastes his talents, the dilettante that endorses a "Pico dela Mirandola" posture; ${ }^{25}$ on the other, there is the profusion of Decadence, the richness of styles, directions and biases milling around. Being a bundle of tensions himself, Delavrancea came to be treated as "a (post)romantic” (Emilia Șt. Milicescu), as a "lyrical/ artistic realist"26 (Tudor Vianu), as "a picturesque realist" (Ion Negoițescu), as "a realist-naturalist” (Nicolae Manolescu), as an author of "social prose" (Mihai Zamfir), or simply as one of the mentionable figures from "the age of great classics." 27 Albeit, one that misses the chance to qualify in the champions' league, being only a "musketeer of the Romanian literature." 28 Truth is that, deserted for a while now on ground of its nationalist and sentimentalist inflexions, Delavrancea's literature cannot be recovered outside the broader context of Romanian Decadence, which, according to Angelo Mitchievici, puts visual sensitivity under the arms of variegated trends such as naturalism, realism, symbolism, and sentimental nationalism (poporanism, sămănătorism). ${ }^{29}$

\section{$\mathscr{1}$}

While many testimonies emphasize on how great Delavrancea was as a political orator, the collection of his speeches represents only a tenth of his works. The proportion oratory vs. literature may be relevant when one compares Delavrancea with Mihail Kogălniceanu, Titu Maiorescu or Take Ionescu, whose oratorical works exceed their literary productions. Apparently, in the same manner as Byron, Delavrancea made his choice for literature as a straighter way to liberty and immortality.
Nonetheless, biographers such as Emilia Șt. Milicescu and Al. Săndulescu show that the beginning of his public career was not unilateral, the young debutante consecrating himself as a promising lecturer in a girls'boarding school, as a potential painter and as a newspaperman interested in the manners of Bucharest mondaine life. In the same fashion as young Kogălniceanu (who delivered his first speeches in front of his girlfriend Niceta), Delavrancea was training his oratorical skills in front of a feminine audience, so the orator's archetypal hypostasis was that of a lover. ${ }^{30}$ The real identity was hidden under various pseudonyms: "Barbu," "Un Visător," "Fra Dolce," "Fra Barbaro," "Fra del Sferza," "Fra," "Argus," "Mirmidon," "Minuzio," "Viator," "d.1.v.," "della Vrancea," "de la Vrancea," and finally "Delavrancea." The first versions of his pseudonym occurred around 1886, while the final form appeared only in 1890 .

It is common knowledge, of course, that "Delavrancea" is the last in a line of pseudonyms, the writer's civil name being Barbu Ștefănescu. The number of pseudonyms (and the myriad of postures indicated hereby) indicates a volatile identity or, in any case, one that is unable to pull together its defining traits; an identity that is looking for legitimation to the higher authority of numbers, expressed later in the concepts of "party" and "people."

The Number - says Delavrancea at the end of his lecture on the Romanian folklore delivered in 1892 - is neither an abstraction nor a meaningless circumstance for creations, for talents, for geniuses. A great man is the product of this Number... The great man is the product of an entire people, 
an apogee of the talents wasted in his people. Naturally, from this draws either the honor or the contempt appended to the Number by some... If we return to folkloric poetry, we actually put back what has been erased by schools [of thought/ of aesthetics, note added] and we pump a stronger Life into the great Life of our race. ${ }^{31}$

As Adrian Tudurachi notices, convoking big data in literary debates (millions, thousands of people) also implies, mathematically speaking, a representation of the people's productivity. ${ }^{32}$ Nevertheless, in Delavrancea's case, the "Number" is not a figure of quantity, an expression of "multitude," but one of passion. The Number measures the intensity of passion. As if drawn up from the Pythagorean esoteric tradition, Delavrancea's Number is the emblem of the Romanian people's virtual energy.

\section{\&}

In 1883, under the pseudonym Argus, Barbu Delavrancea became acknowledged as a prose writer with the short story Sultănica. This was followed by "Şuer," "Fanta-Cella," "Iancu Moroi," "Palatul de Cleștar," "Răzmirița” (1884), "Sorcova," "Odinioară” (1885), "Zobie," "Trubadurul," "Din memoriile trubadurului," "Văduvele" (1886), "Milogul," "Hagi-Tudose," "Apă și foc," "Lene," "Liniște" (1887), "Bursierul," "Domnul Vucea," "Sentino," "Înainte de alegeri," "Pravoslavnicul și slăninele," "Moș Crăciun” (1888), "Neghiniță,” "Poveste," “Nu e 'giaba' cafea”(1889), "Irinel”(1890), "Paraziții” (1892), "Norocul dracului,” "Dăparte, dăparte," “Bunicul,” "Bunica,” “Două lacrimi," "Marele Duce"(1893), "De azi și de demult," "Micutii" (1894). Unfinished, the last one was announced publicly as "a couple of notes extracted from Delavrancea's notebook of impressions." Among the aforementioned titles, "Trubadurul," "Liniște" and "Parazitiii" should be judged as tropisms, as "psychological micro-novels," as trials of recovering the moment of glory. They evince - in Mihai Zamfir's opinion - Delavrancea's "lack of calling for theoretical analysis." 33 Anyhow, the writer's appetite for theory in his micro-novels does not solve the following problems: Why was Delavrancea always returning to the springs of his inspiration? How was the energetic exchange between literature and oratory, or between the speech's aura and its afterlife "copies" made?

If they turned to the heroes' profiles, the readers could notice the Byronic vein running throughout; Delavrancea's fictional personae are half-melancholic and half-declamatory, as if all of them were preparing verbal ammunition for the real person's forthcoming political career. The Troubadour's aphorisms (from the text entitled "The Troubadour's Memoirs") do not catch attention through their mere contents, but through their formal simplicity and logic, which makes them perfect as ready-made bon mots for the great speeches to come.

Once the literary interests developed around 1880 were left aside, Delavrancea opened the next decade with a pamphlet against Queen Elizabeth of Romania/ Carmen Sylva's literature and memoirs. The attack was bolstered by arguments against Carmen Sylva's raw and naturalist way of picturing Romanian folklore and customs. The rebuke sounds rather strange if one takes into consideration that Delavrancea himself used to write in the same naturalist style, 
using strong, almost clogged colors in "Zobie,"“Milogul," “Apă și foc” and suchlike.

Between 1892 and 1893, we find the ex-writer as a deputy lecturer at the Faculty of Letters of Bucharest. His topic was, of course, the bounty of the Romanian Folklore, which he praised now not as "a promise of limitless aestheticization" (in Alecsandri's manner), ${ }^{34}$ but as a promise of limitless energy and Life. Despite their incompleteness, these lectures encompass enough hints on passion (considered a racial and individual trait at the same time), on mnemonics based on the force of plastic verbs (also called, "whole verbs" or "resuming verbs"), and on "the Number" (the force of the people).

In November 1894, Barbu Delavrancea finally began his political career. As a reputed speaker of the parliamentary tribune, the young Liberal was extremely active in 1895 , immediately after his election, when he delivered no less than 17 speeches. When he was on the verge of parting with the Liberals (1898-1899), Delavrancea went to the tribune about the same number of times. In 1901 and 1909, he took the floor only once; in-between these nine years he was as silent as a grave. In 1909, he returned to literature and produced the first two plays from Moldavia's trilogy, Apus de soare and Viforul, followed by Luceafärul in 1910. With all its fairy-tale ${ }^{35}$ and liturgical diction, ${ }^{36}$ this trilogy was a success and became the most visited item of the writer's entire work. Toward the end of his career, Delavrancea baffled the public opinion with an eccentric choice. Mysteriously, he chose to reevaluate the controversial themes of his early prose: incest ("Irinel"), adultery and sycophancy ("A doua conștiință") and monomaniacal penny-pinching ("Hagi Tudose").
Some commentators tried to prove, stylistics in hand, that Delavrancea's phrase "evolved" from a luxuriant structure (full of epithets and influenced by Alphonse Daudet) to a syntax ruled by simple and austere sentences, hence from a verbose to a concise formula. ${ }^{37}$ Taking into consideration that some of the early short stories count on the effects of chopped syntax, the evolution from much to less is rather inconceivable. On the contrary, the enlargement of short stories into theatre plays, the intra-fictional exercises of declamation (both within the micro-novels and within the plays of Moldavia's trilogy), as well as the oratorical texts prove the contrary: Delavrancea's style grew from little to more, from true Life to wasted transcriptions, and from true patriotism to... "a new way of cooking the national spinach," as Caragiale derisively referred to his friend's attempts at writing historical plays. ${ }^{38}$ Still, if we turn back to the Number's outstanding energy, either of the two types of aesthetic evolution (from much to less or from little to more) seems equally false. Based on the exchange of heat and energy, Delavrancea's work does not respect the algorithm of evolution but the laws of thermodynamic systems whose dominant concept is entropy and whose dominant drive is to return to the point of departure.

\section{The Terror of Written Words and the Pleasure of Telling Stories}

厂n ndeed, the late plays Irinel (1912), Hagi Tudose (1912) and The Second Consciousness (1914) dramatized loosely the short stories published before 1894 . The naturalist writings affected now a sort of black humor. They were "comedies" built in the fashion of Caragiale and Alecsandri's 
comedies of manners, on a refurbished naturalist foundation. Accordingly, Ion Negoițescu noticed that, while Moldova's trilogy was the golden fruit of Delavrancea's eloquence, the late plays tended to pulverize this "dramatic spirit." ${ }^{39}$ Clearly indicating their origin and perhaps their original success two decades before, the first two texts preserved the original titles. Notwithstanding its changed title, the latter was a sum of former narrative situations and types, blending Byronic figures already used in "Paraziții," "Trubadurul" and "Liniște." In fact, Emilia Șt. Milicescu has already shown that, as early as 1893 , Delavrancea was already planning to enlarge and recycle his stories in order to write a political novel entitled Criminalii legalil The Legal Criminals. ${ }^{40}$

Iorgu, the unadapted type from Iri$n e l$, falls in love with his cousin. So far, the subject contains a recognizable, almost phosphorescent romantic trait: incest as "a poetic circumstance" indicating the broader theme of the double. Delavrancea points out from his first scenic indications a bizarre detail. The main character is somehow connected with the Moldavian chronicles, edited by Mihail Kogălniceanu between 1845 and 1852; in the first scene, they are on his table as if recently consulted. Even if Iorgu is a brilliant lawyer-to-be and a rich inheritor, the character is utterly unhappy and seems to be touched by a curse. His love for his cousin clarifies the nature of Iorgu's fate: he is doomed to repeat a typical episode of incest contained in the old chronicles he kept on reading. Paralyzed by the terror of written words to the same extent as Eugen Lovinescu's Bizu (who glances at his lover's profile in G. Sion's old Arhondologia), ${ }^{41}$ Iorgu's love grows illicit out of too much reading. It is not physiological morbidity, but mere words that are the vectors of his strange infatuation with his cousin Irinel.

Regarding the dramatization or, better, the enlargement of Hagi Tudose, critics have remarked that Delavrancea did nothing else but amplify the biography of the main character. Hence, this second version of avarice breathes "a good-humored patriarchal air." ${ }^{42}$ As compared to the previous version, the Romanian Harpagon's personality results in a smoother version mainly due to his oriental appetite for the spoken word. If Iorgu seems to be scared by the power of written words, Hagi Tudose derives pleasure from his own spoken words. Even though the pleasure of wasting words comes in flagrant contradiction with Hagi Tudose's monomaniacal avarice, Delavrancea stages him now in the part of a storyteller who narrates with obvious gusto a set of pilgrimage adventures. The other characters that form the audience seem captivated, which is enough proof of this storyteller's talents. Hagi Tudose here resembles old Giaba from "Nu e 'giaba' cafea," a Turk who manages to turn words into real gold like the sophists of the old times: the listeners at the village coffee shop pay him to tell them stories. Overall, the play is a potpourri of previous motifs: the considerations on the styles of religious painting come from Delavracea's articles on art; the children's games in the city's outskirts originate in "Odinioră" and "Domnul Vucea"; the exploitation of the beggars has been the theme of "Milogul" and "Zobie"; Leana, Hagi Tudose's niece, embodies the purity and strength of Romanian women, consecrated in "Sultănica" and "Susana."

Mihai Zamfir noticed the minute indications of Delavrancea's didascalies. The 
observation is also valid for Irinel and $A$ doua conștiință. The manuscript pages of these late plays demonstrate, beyond the shadow of a doubt, that the writer created through means of representation, by drawing faces and scenes first. The writer's tendency toward enlargement (dramatization) seems to be controlled by the painter's ability to capture the world in a single frame. Consequently, words name things, people and settings that have been already created through means of vivid imagination; hence, things, people and settings can be visualized not only as figures on paper, but also as imagines agentes.

Taking into consideration Cicero's well-known theory on the importance of loci and imagines for the mnemonic process, we can presume that the writer's talent for drawing must also have assisted him in the preparation of speeches. Before speaking or writing, Delavrancea was able to see, remember and recreate faces. An all-encompassing sense of sight bridges Dealavrancea's oratory and literature.

\section{The "Phosphorescent Note," "Plastic Verb" and "National Fixation"}

Sight has a tremendous importance in the theories devoted to eloquence. Suffice it to say that Quintilian recommended that the entire sensorium should be transferred into visual images. ${ }^{43}$ Another ancient text establishes that, unless he wants to memorize his speech, the orator should endeavor to form two types of images: on the one hand, images for things (res), on the other, images for words (verba). But why, the Ancient rhetoricians inquired, could some images awake memory while others could not? The answer must be searched for in the theory of imagines agentes (active images), which refers to the orator's capacity to figure out discoursed issues as a drama, thus as a series of human faces engaged in active hypostases:

We ought, then, to set up images of a kind that can adhere longest in the memory. And we shall do so if we establish likenesses as striking as possible; if we set up images that are not many or vague, but doing something; if we assign to them exceptional beauty or singular ugliness; if we dress some of them with crowns or purple cloaks, for example, so that the likeness may be more distinct to us; or if we somehow disfigure them, as by introducing one stained with blood or soiled with mud or smeared with red paint, so that its form is more striking, or by assigning certain comic effects to our images, for that, too, will ensure our remembering them more readily. The things we easily remember when they are real we likewise remember without difficulty when they are figments, if they have been carefully delineated. But this will be essential again and again to run over rapidly in the mind all the original backgrounds in order to refresh the images. ${ }^{44}$

If imagines agentes are images that impress the orator's soul to such an extent that he finally recalls them, then they carry the same effect on the orator's audience. Faced with imagines agentes, the public's senses are induced into feeling the proximity of Life. Sipping in these fundamental principles, Barbu Delavrancea subsequently theorized the plastic verb as an aggregation 
of notions, a feature that makes it the basic mnemonic principle in the transmission of oral culture:

In folkloric poetry, the predominant element is the verb... The verbs that comprise a sum of notions - accompanied by a modality, a qualification, a color, are plastic, whereas the others, which awaken something without plasticity, are abstract... A plastic verb comprises several actions and its discharge is more powerful than individual actions, verbs, even adverbs and adjectives encompassed thereby... This psychological phenomenon resembles mechanics. If we hit someone with a billiard ball three times and with equal force, the person would be punched three times equally; but if we summed up the force of the three billiard balls and we hit only once, the person would receive only one impression instead of three, more powerful and lasting than in the first place. A resuming verb [verb-sum] produces in us an explosion of life and light; if we cut this verb into pieces, the impressions are colder and cause drowsiness [emphasis added]. ${ }^{45}$

\section{$\mathscr{D}$}

In spite of Delavrancea's apparent knowledge in the art of eloquence, neither the aesthetic nor the rhetoric accomplishments should call our interest here. In Delavrancea's case, the mechanism of rewriting - and of his literary pursuits on the whole - is not pushed by a drive to stylization, but by the processes of anamnesis and emulation specific to his unsteady "I."
Indeed, recycling the experiences of former glory and of estranged self is the chief aim of Delavrancea's late plays (Irinel, $\mathrm{Ha}$ gi-Tudose, $A$ doua conștiință). And this is obvious on the thematic level too.

For instance, the character from $A$ doua conștiință is a successful lawyer reputed for his eloquence. His only fixation in life is Mona Lisa's smile. After many years of deep contemplation, Rudolf tends to see in Da Vinci's painting a picture of his own clean consciousness. As a lawyer, he has never accepted compromise. As a public man, he has been guided only by his unfaltering patriotism. However, when Mona Lisa steps off the painting in the person of Melanie, his wife's cousin, the lawyer has to face with his own embodied consciousness. This process of embodiment triggers Rudolf's tragedy: from a lover of ideas he turns into an adulterer, a passionate Don Juan who will be subjected, from now on, to irreversible corruption. The play is an allegory on the corruption of great orators; the embodiment of great messages also means falling into decay.

Why should Delavrancea recycle his lost pieces (on incest, adultery, corruption, hoarding), when his acceptance in the Romanian Academy was imminent and the public had already acclaimed him as one of the greatest writers of the Romanian nation? Did the Byronic hero, did the successful orator/ writer have any doubts about his own value? Surely, being Caragiale's friend did not seem to help his ego at all. In fact, Caragiale was the first writer that, catching Delavrancea's mannerisms, mocked the style of "Sultănica" and "Stăpânea odată." The "para-intelligent" Caragiale was also the grimmest critic of Delavrancea's historical plays. ${ }^{47}$ It is reported that the two 
writers shared in common the cult for Beethoven's divine music and - Take Ionescu confirmed in a letter - a secret inclination for political power. Caragiale thought that Delavrancea did not have any calling for theatre, but appreciated Delavrancea's visual and lexical aptness as well as his gift for oratory; in his turn, Delavrancea admired Caragiale's theatre, but disagreed with his friend's derisive way of treating the cause of the Romanian people's emancipation. In fact, Caragiale summarized their relationship as a love-hate mechanism.

At first - Caragiale admitted - we got along without loving each other; then, we loved each other without understanding each other; only late, once with age, we got over everything, and we get along because we love each other, and we love each other because we get along. ${ }^{48}$

Exploring the archeology of collective passions, Adrian Tudurachi emphasizes the difference between "imitation" and "emulation" attitudes: while imitation departs from a religious tradition based on loyalty and obedience to the model, emulation comes from the rhetorical tradition and implies "equal and concurrent" actors, engaged in a "violent rivalry." Nevertheless, the difference between "imitators" and "emulators" is perceivable only when irreducible passions such as jealousy, envy, lust, fury or revenge come into play. ${ }^{49}$ "To love something that you cannot understand" is the first step in mobilizing the factory of literature on both collective and individual levels. Accordingly, literary friendships are, due to implied emulation, such "factories of literature." Apparently, the same mechanism of emulation - competition, violent rivalry and passion at the same time - is applicable in the precise case of the Delavrancea-Caragiale relationship. By loving something he could not understand completely - that is, Caragiale's talent - Delavrancea committed himself to writing theatre. If he failed, he failed out of too much zeal.

\section{\&}

After all, Delavrancea never ceased to say that violent passion was the dominant key of both his personality and race. "In national issues," said the politician while still a Liberal, "the people's passions are what gives force, resolution and ensures rights. ${ }^{" 50}$ "Only such people, with live and quick passions, with deep and fiery feelings, with a strong and passionate nervous system - fine and rich and explosive at the same time could arrive at the notion of longing (dor)." “The Romanian people's love is hot, intense and spontaneous," Delavrancea declared in his lectures on Romanian folklore. Moreover, spontaneity is the outer expression of mobility and sincerity. ${ }^{52}$ It is not by chance thus that, guided by their view on spontaneity-mobility-sincerity, Take Ionescu and Delavrancea became the main promotors of a "politics of the heart." Beyond hybridized doctrines and debatable moral attitudes, the stress on subjectivity and passion was a common trait of all young politicians who started their careers on the crest of a populist wave around $1885 .{ }^{53}$ Similarly, this theory insisting on the Romanian people's racial dominant would serve Delavrancea perfectly in his endeavor to propose a popular oratorical model differing from the consecrated style of Titu Maiorescu's 
dispassionate, Apollonian (sometimes thoroughly boring) speeches. ${ }^{54}$

The Byronic protagonist of the short-stories "The Troubadour" and "The Troubadour's Memoirs" ends his collection of aphorisms and bon mots with a contemplation of battle and passion: "The stronger one punches the adversary, the more is one assured that he won't get up in his feet. Passion instead is like a ball: the stronger you punch it, the higher it pops up." ${ }^{55}$ Passion, Delavrancea believes, glues all the impressions conveyed through senses. Passion is the foundation of sensorium, which, in its turn, mobilizes the relationship orator-audience. Passion is also the engine of plastic verbs in both literature and oratory; its effectiveness lies in the sum of notions (imagines agentes) encompassed within. It follows that the knowledge and use of such verbs is meant to engage passion and make the audience and the speaker share the one and the same sensorium.

\section{\&}

The wanted success came for the orator in less than a decade. "The Danubian peasant" - this is the way Delavrancea styled himself in his maiden speech in November 1894 - was finally praised as "a Romanian Gambetta," as "the greatest political orator of Europe." ${ }^{56}$ Fire was the distinctive note of his eloquence. Eugen Lovinescu, Take Ionescu, and others compared Delavrancea's speeches with flames that erupted from the ground and burned the skies. ${ }^{57}$ Inspired by the writer's lectures on the Romanian folklore, Tudor Vianu confirmed that, shaped on visual coordinates, his eloquence gained a "phosphorescent note," a drive for synthesis. The same goes for the prose whose "fundamental hallucinogenic tone engulfs all the other sensations as white usually engulfs the other colors." ${ }^{58}$

In spite of his notorious party switching - from Conservatives to Liberals and backward, commentators contemplate Delavrancea's political oratory as a coherent synthesis ${ }^{59}$ that can be boiled down to his obstinate advocacy for the national issue ("chestiunea națională"). Concerning chiefly the status of the Romanians from the provinces of Transylvania, Bessarabia and Bukowina, the national issue meant for Delavrancea more than a plea for union:

I'm a poor man, I'm not able to make many fixations... Instead, I'm having only one fixation: the national issue. Everything that I have thought, written and spoken has developed from and with this idea. ${ }^{60}$

In his maiden speech, he declared that the national issue subsumed all the other issues concerning the Romanian people's life: agriculture, land property, education, military policies. ${ }^{61}$ The national issue was the ideology of the people without names ("cultul celor mici"). ${ }^{62}$ It sprang from the intuition that the "enlightened Number" 63 could shed onto the orator a new form of legitimizing force. It was not the vote that gave political legitimacy but the capacity to channel out the profound Voice of the many.

\section{Transfusions: from Name to People and Backwards}

sI have already pointed out, the entro-
py of pseudonyms (and literary styles)
indicates a volatile identity, unable to pull
together its defining traits. The assumption 
may sound rather uncustomary, especially if one takes into consideration Delavrancea's obstinate recoiling on three synthetic categories: "the phosphorescent note" (logos), "the plastic verb" (pathos), "the national issue" (ethos).

Inquiring on how fakes influenced the transmission of cultural memory, Judith Schlanger notices that plagiarism, apocryphal writings, pseudonyms, and all copying attitudes in general are meant to provide density to (real) names. All of us must have experienced the taste of growing dissipation when put beside consecrated names. It is for this reason that the lack of identity (anonymity) and pseudonym have never been perceived as imposture or fraud (even if, legally speaking, they are), but as an act of heroism. ${ }^{64}$

Was Barbu Ștefănescu really heroic when he gave up his real name and became "Delavrancea"? As a literate, he was. In the beginning, the melancholic Troubadour masked riotous ideas and barbarous offences through pseudonyms. Eventually, the pseudonym came to cover a disturbing void of identity and a temper ready to emulate glorious models (Caragiale). In this case, the pseudonym "Delavrancea" stands for a multitude of postures, for the Number. Yet, as a politician, Barbu Delavrancea was not so heroic when he decided to run for an MP seat under a (legally) false name. The political posture makes the pseudonym lose its former heroic air (held within the realm of literature). Recovering former literary successes and stating racial determinations became Delavrancea's favorite techniques of giving consistency, of pumping fresh blood into a false signature:

Delavrancea is only a pseudonym that I have used for 12 years now. All this time, friends, acquaintances, and even people that didn't know me ended up calling me this way in both speaking and writing. Thus, more than my use of it, the use of others made the pseudonym prevail over my name. ${ }^{65}$

It is clear now: the public baptized the writer and he bears their name. The sense of identity enhances with the augmentation of the admirers' number. "Delavrancea" is a signature legitimized by the authority of the Number, thus something that receives the discharged energy of the Number.

\section{g}

The successful political orator had always paraded his consistency with the national issue. This used to be displayed as a unique concern, as "the phosphorescent note" of his public discharges. Still, if we get closer to his speeches from 1895 , a second theme surfaces with even greater power: the name issue. Amplified by the Conservatives' initiative to pass a law on Romanian aristocratic names, the name issue gained prominence beforehand, when Delavrancea was attacked on the grounds that, during the electoral campaign, he made use of his literary pseudonym. ${ }^{6}$ Indeed, Al. Marghiloman (himself the offspring of an old aristocratic family) wanted to pass, derisively, a decree on Barbu Ștefănescu's right to be called "Delavrancea" within the Parliament premises. ${ }^{67}$ As a safety escape from this unbearable context, the writer declared that he did not need to parade a certificate of heraldry like the Romanian boyars did most of the times; the literary name provided here a greater political legitimacy. 
Baffling the Conservatives' protectionist measure, Delavrancea's ensuing speeches emulated and expanded Alecsandri's and Caragiale's ideas on the ontological grounding of names. ${ }^{68}$ Raising roars of laughter among his fellow MPs, the orator exploited the comic effects of names. Convoked in parliamentary debates several times before Delavrancea's speeches on the name issue, Caragiale's plays $O$ noapte furtunoasă and $O$ scrisoare pierdută were already common references for all Romanian politicians. All in all, Delavrancea's political approach on names was justified in a literary fashion: people should not be linked, by force of law, with a family name; if necessary, anyone should be able to change it; sometimes a nickname or a pseudonym could have a greater ontological relevance than the real name.

Extremely intuitive in all matters, the Romanian writer must have suspected, again, that the aporia speaking-writing led to another blind alley: the tension between singularity and species. So he kept on relying on Race and Number as determiners of his own talent and pseudonym. In terms of social organization, the Number actualized for Delavrancea as "party" members and, respectively, as "people." Whenever the party's Number disappointed him, Delavrancea resorted to the mighty authority of the people's Number.

The role of aggregated and embodied passions in the exchanges of legitimacies between pseudonym and race is obvious, especially if one resorts to the rich tropes of "blood" and "transfusion." The micro-novel Linişte, for instance, features a physician who has suffered from talking too much and who decides, after a series of disappointments, to keep silence for the rest of his life. Still, the physician's strange quietness is also linked with a failed experiment of blood transfusion between him and his wife. Similarly, the figure of blood-sucking underlies the social parasitism described in "Paraziții" and "Iancu Moroi." The readers should not be astonished when discovering that, following Delavrancea's interest in physiology, the orator's real correspondent is not the man of letters but the physician, thus the one who holds the secrets of flesh and blood, of glory and corruption.

Race and blood are meant to give consistence to the pseudonym and to the writer's "second consciousness." Yet, when the pseudonym or consciousness become embodied (as in the play $A$ doua conștiint, ă), they subject the orator to corruption and decay; they make him lose the moment of glory and doom him to act it repeatedly in literary forms. Placed at the crossroads of oral delivery and writing, of singularity and species, of type and token (Number), Delavrancea's career problematizes the difficult relationship between the orator's momentous glory and the literate's failed attempts to recreate the aura. In this case, the amount of failures indicates the intensity of passions involved in the sensorial exchanges among the speaker, audience, cultural tradition and environment. 


\section{WORKS CITED}

Benjamin, Walter, The Work of Art in the Age of Mechanical Reproduction, http://www.udel.edu/History/ suisman/611_S05_webpage/benjamin-work-of-art.pdf, accesat în 16.03. 2013

Caragiale, I.L., Opere. Corespondență, vol. 7, Bucharest, ESPLA, 1942

Cicero, Brutus - Orator, translated by G.L. Hendrickson and H.M. Hubbel, Loeb Classical Library, Harvard, Harvard UP, 1939

Cioculescu, Șerban, Ovidiu Papadima, Alexandru Piru (eds.), Istoria literaturii românel The History of Romanian Literature, vol. 3, Bucharest, Academia RSR Publishers, 1973

Cubleșan, Constantin, Opera literară a lui Delavrancea, Bucharest, Minerva Publishers, 1982

Delavrancea, Barbu, Opere I/ Works 1, edited by Emilia Șt. Milicescu, Bucharest, EPL Publishers, 1965

Delavrancea, Barbu, Opere V/ Works 5, edited by Emilia S,t. Milicescu, Bucharest, Minerva Publishers, 1969

Delavrancea, Barbu, Opere VIIL/ Works 8, edited by Emilia Șt. Milicescu, Bucharest, Minerva Publishers, 1971

Didi-Huberman, Georges, Peoples exposés, peoples figurés, Paris, Minuit, 2012

Florescu,Vasile, Retorica și neoretorica, Bucharest, Academia RSR Publishers, 1973

Goia, Vistian, Destine parlamentare. De la Mihail Kogălniceanu la Nicolae Titulescul Parliamentary Destinies. From Mihail Kogălniceanu to Nicolae Titulescu, Cluj Napoca, "Dacia” Publishers, 2004

Hawhee, Debra, “Rhetoric's Sensorium,” Quarterly Journal of Speech, 1 (101), 2015, pp. 2-17

Ibrăileanu, G., Scrieri alese, selection of texts, prefatory note, timeline and critical references by Antonio Patraș and Roxana Patraș, Iași, "Alexandru Ioan Cuza” UP, 2010

Maiorescu, Titu, Opere. I. Critice, edited by D. Vatamaniuc, introduction by Eugen Simion, Bucharest, FNSA-Univers Enciclopedic Publishers, 2005

Manolescu, Nicolae, Istoria critică a literaturii române. 5 secole de literatură, Pitești, Paralela 45 Publishers, 2008

Milicescu, Emilia Șt., Delavrancea, Cluj-Napoca, Dacia Publishers, 1975

Mitchievici, Angelo, Decadență și decadentism în contextul modernității românești și europene (sfârșitul secolului al XIX-lea, prima jumătate a secolului XX), Bucharest, Curtea Veche Publishers, 2011

Mitchievici, Angelo, Simbolism și decadentism în arta 1900, prefață de Ioana Vlasiu, Iași, Institutul European Publishers, 2011

Negoițescu, Ion, Istoria literaturii române, Bucharest, Minerva Publishers, 1991

Niculescu, Al., Structura frazei in stilul lui B. Delavrancea, Bucharest, Academia RSR Publishers, 1956

Oratorie politică românească (1847-1899), vol. 3, edited by Roxana Patraș, "Alexandru Ioan Cuza" University Press, 2016

Patraș, Roxana, "On Diffident and Dissident Practices: a Picture of Romania at the End of the 19th Century," Symposion. Theoretical and Applied Inquiries on Philosophy and Social Sciences, 2, 1 (2015), pp. 35-51.

Patraș, Roxana, "What Is under the Hood of $19^{\text {th }}$-century Political Eloquence? Autobiographic Instances as Propellers of Lifelong Careers," in Iulian Boldea (ed.), Globalization and National Identity. Studies on the Strategies of Intercultural Dialogue, Tîrgu-Mureş, Arhipelag XXI Press, 2016, pp. 294-309 Quintilian, Institutes of Oratory, vol. 1, 2, 3, translated into Romanian by Maria Hetco, Bucharest, Minerva Publishers, 1974

Reid, Christopher, "Whose Parliament? Political Oratory and Print Culture in the Later $18^{\text {th }}$ Century," Language and Literature, 9.2 (2000), pp. 122-134

Saguar García, Amaranta, "The Concept of Imago Agens in Celestina: Text and Image," Celestinesca, 39 (2015)

Săndulescu, Al., Delavrancea, EPL Publishers, Bucharest, 1964

Schaeffer, Jean-Marie, Les Célibataires de l'Art. Pour une esthétique sans mythes, Paris, Gallimard, 1996 Schlanger, Judith, Présence des oeuvres perdues, Paris, Herman Éditeurs, 2010 
Taylor, David Francis, "Byron, Sheridan, and the Afterlife of Eloquence," Review of English Studies, 65 (2014), pp. 474-494

Torouțiu, I.E., G. Cardaș, Studii și documente literare/ Literary Studies and Documents, vol. I, Bucharest, Inst de Arte Grafice "Bucovina," 1931

Tudurachi, Adrian, Fabrica de geniu. Nașterea unei mitologii a productivității literare în cultura română (1825-1875), Iași, Institutul European Publishers, 2016

Tudurachi, Ligia, Cuvintele care ucid. Memorie literară în romanele lui E. Lovinescu, Cluj-Napoca, Limes Publishers, 2010

Vianu, Tudor, Scriitori români, in Opere 2, Bucharest, Minerva Publishers, 1972

Vianu,Tudor, Arta prozatorilor romani, vol. 1, Bucharest, EPL Publishers, 1966

Yates, Frances, The Art of Memory, London \& New York, Routledge, 1966 (reprinted in 1999)

Zamfir, Mihai, Scurtă istorie. Panorama alternative a literaturii române, București-Iași, Cartea românească-Polirom Publishers, 2011

\section{NoTES}

1. Cicero, Brutus - Orator, translated by G.L. Hendrickson and H.M. Hubbel, Loeb Classical Library, Harvard, Harvard UP, 1939, p. 45.

2. Quintilian, Institutes of Oratory, vol. 1, translated into Romanian by Maria Hetco, Bucharest, Minerva Publishers, 1974, p. 232; Institutes of Oratory, vol. 3, p. 333.

3. Vasile Florescu, Retorica și neoretorica, Bucharest, Academia RSR Publishers, 1973, p. 23.

4. David Francis Taylor, "Byron, Sheridan, and the Afterlife of Eloquence," Review of English Studies, 65 (2014), p. 475.

5. Ibid., p. 479.

6. Christopher Reid, "Whose Parliament? Political Oratory and Print Culture in the Later $18^{\text {th }}$ Century," Language and Literature, 9.2 (2000), p. 127.

7. Walter Benjamin, The Work of Art in the Age of Mechanical Reproduction, http://www.udel.edu/History/suisman/611_S05_webpage/benjamin-work-of-art.pdf, accesat în 16.03.2013.

8. William Hazlitt, On the Difference between Writing and Speaking, qtd. in David Francis Taylor, op. cit., p. 481.

9. David Francis Taylor, "Byron, Sheridan, and the Afterlife of Eloquence," p. 484.

10. Ibid., p. 489.

11. Tudor Vianu, "Delavrancea," in Scriitori români, in Opere 2, Bucharest, Minerva Publishers, 1972, p. 594.

12. Alexandru Vlahuță (1858-1919), Duiliu Zamfirescu (1858-1922), George Coșbuc (1866-1918), Alexandru Macedonski (1854-1920), Ștefan Octavian Iosif (1875-1913), Dimitrie Anghel (18721914), Calistrat Hogaș (1847-1917), Al. Davila (1862-1929) etc.

13. Mihai Zamfir, "Partea II. Sfârșitul secolului"/ $2^{\text {nd }}$ Part. The End of the Century, in Scurtă istorie. Panorama alternativă a literaturii române, București-Iași, Cartea românească-Polirom Publishers, 2011, p. 350 .

14. A. Vlahuță, Delavrancea's friend, introduced the term "curentul Eminescu"/ Eminescu's school in a conference delivered at the Romanian Athenaeum in 1892. Refining Vlahuțăs ideas, G. Ibrăileanu published in 1909 a study showing, from its title ("Curentul eminescian"/ The Eminescian school), that the name "Eminescu" had been already turned into the stylistic feature "eminescian" (viz. G. Ibrăileanu, Scrieri alese, selection of texts, prefatory note, timeline and critical references by Antonio Patraș and Roxana Patraș, Iași, “Alexandru Ioan Cuza” UP, 2010, pp. 301-316).

15. I. Negoițescu, “Cap VIII. Literatura română în jurul anului 1900,” in Istoria literaturii române, Bucharest, Minerva Publishers, 1991, pp. 130-143.

16. Mihai Zamfir, Scurtă istorie..., pp. 315-433. Nicolae Manolescu discusses Delavrancea's contribution in a still larger frame containing both the end of the nineteenth century and the beginning of the 
following (viz. Nicolae Manolescu, "Sfârșit de secol, început de secol"/ The end of the (nineteenth) century, beginning of the (twentieth) century, in Istoria critică a literaturii române. 5 secole de literatură, Pitești, Paralela 45 Publishers, 2008, pp. 453-550).

17. Titu Maiorescu, „Oratori, retori și limbuți”/ Orators, rhetoricians, and gabblers, in Opere. I. Critice, edited by D. Vatamaniuc, introduction by Eugen Simion, Bucharest, FNSA-Univers Enciclopedic Publishers, 2005, p. 718.

18. Vistian Goia, "Barbu Delavrancea - Vehemența oratorului"/ Barbu Delavrancea - The Orator's Vehemence, in Destine parlamentare. De la Mihail Kogälniceanu la Nicolae Titulescu/ Parliamentary Destinies. From Mibail Kogălniceanu to Nicolae Titulescu, Cluj Napoca, "Dacia” Publishers, 2004, pp. 142-150.

19. I.E. Torouțiu, G. Cardaș, Studii și documente literare/ Literary Studies and Documents, vol. I, Bucharest, Institutul de Arte Grafice "Bucovina," 1931, pp. 31-33.

20. Barbu Delavrancea, Opere V/Works 5, edited by Emilia Șt. Milicescu, Bucharest, Minerva Publishers, 1969, pp. 745-746.

21. Emilia Șt. Milicescu, Delavrancea, Cluj-Napoca, Dacia Publishers, 1975, pp. 216-268; Constantin Cubleșan, Opera literară a lui Delavrancea, Bucharest, Minerva Publishers, 1982, pp. 13-65; Vistian Goia, "Barbu Delavrancea - Vehemența oratorului"/ Barbu Delavrancea - The Orator's Vehemence, in Destine..., pp. 142-150.

22. Jean-Marie Schaeffer, Les Célibataires de l'Art. Pour une esthétique sans mythes, Paris, Gallimard, 1996, pp. 121-184.

23. Judith Schlanger, Présence des oeuvres perdues, Paris, Herman Éditeurs, 2010, pp. 9-17.

24. Debra Hawhee, "Rhetoric's Sensorium," Quarterly Journal of Speech, 1 (101), 2015, pp. 2-17.

25. Pic de la Mirandole - Minunea colectiviștilor, Desen de Barbu Delavrancea, in Opere V, p. 416.

26. Tudor Vianu, "Realismul artistic și liric"/ Lyrical and Artistic Realism, in Arta prozatorilor romani, vol. 1, Bucharest, EPL Publishers, 1966, pp. 235-261.

27. Al. Săndulescu, "Delavrancea," in Șerban Cioculescu, Ovidiu Papadima, Alexandru Piru (coord.), Istoria literaturii românel The History of Romanian Literature, vol. 3, Bucharest, Academia RSR Publishers, 1973, pp. 699-741.

28. C. Săteanu, "Mușchetarii literaturii române - Al. Vlahuță, I.L. Caragiale, Delavrancea și Coșbuc," qtd. in Emilia Șt. Milicescu, "Introduction" to Opere I/ Works 1, edited by Emilia Șt. Milicescu, Bucharest, EPL Publishers, 1965, p. XLVII.

29. Angelo Mitchievici, Decadență și decadentism în contextul modernității românești și europene (sfârșitul secolului al XIX-lea, prima jumătate a secolului XX), Bucharest, Curtea Veche Publishers, 2011; Simbolism și decadentism in arta 1900, foreword by Ioana Vlasiu, Iași, Institutul European Publishers, 2011.

30. Roxana Patraș, "What Is under the Hood of $19^{\text {th }}$-century Political Eloquence? Autobiographic Instances as Propellers of Lifelong Careers," in Iulian Boldea (ed.), Globalization and National Identity. Studies on the Strategies of Intercultural Dialogue, Tîrgu-Mureş, Arhipelag XXI Press, 2016, pp. 294-309. 31. Barbu Delavrancea, Opere V/ Works 5, p. 628.

32. Adrian Tudurachi, Fabrica de geniu. Nașterea unei mitologii a productivității literare în cultura română (1825-1875), Iași, Institutul European Publishers, 2016, pp. 61-64.

33. Mihai Zamfir, Scurtă istorie... p. 353.

34. Adrian Tudurachi, Fabrica..., p. 161.

35. Mihai Zamfir, Scurtă istorie..., p. 353.

36. Ion Negoițescu, Istoria..., p. 133.

37. Al. Niculescu, Structura frazei in stilul lui B. Delavrancea, Bucharest, Academia RSR Publishers, 1956.

38. Din corespondența inedită a lui Caragiale, edited by Șerban Cioculescu, qtd. in Emilia Șt. Milicescu, Delavrancea..., p. 161, 163.

39. Ion Negoițescu, Istoria..., p. 133.

40. Emilia Șt. Milicescu, Delavrancea..., pp. 121-122.

41. Ligia Tudurachi, Cuvintele care ucid. Memorie literară în romanele lui E. Lovinescu, Cluj-Napoca, Limes Publishers, 2010, pp. 65-67. 
42. Mihai Zamfir, Scurtă istorie..., p. 354.

43. Frances Yates, The Art of Memory, Routledge, London \& New York, 1966 (reprinted in 1999), p. 4. 44. Rhetorica ad Herennium, qtd. in Amaranta Saguar García, "The Concept of Imago Agens in Celestina: Text and Image," Celestinesca, 39 (2015), p. 248.

45. Barbu Delavrancea, Opere V/ Works 5, pp. 558-568, 574-580.

46. Al. Săndulescu, Delavrancea, pp. 184-186.

47. Emilia Șt. Milicescu, Delavrancea, pp. 161-164.

48. I.L. Caragiale, Opere. Corespondență, vol. 7, Bucharest, ESPLA, 1942, p. 245.

49. Adrian Tudurachi, Fabrica..., pp. 171-173.

50. Barbu Delavrancea, Opere VIII/ Works 8, edited by Emilia Șt. Milicescu, Bucharest, Minerva Publishers, 1971, p. 41.

51. Barbu Delavrancea, Opere V/ Works 5, p. 614, 618.

52. Idem, p. 619.

53. Roxana Patraș, "On Diffident and Dissident Practices: a Picture of Romania at the End of the 19th Century," Symposion. Theoretical and Applied Inquiries on Philosophy and Social Sciences, 2, 1 (2015), pp. 35-51.

54. Barbu Delavrancea, "Discursul dlui Delavrancea rostit in ședința de la 9 decembrie 1894 a Camerei Deputaților," in Oratorie politică românească (1847-1899), vol. 3, edited by Roxana Patraș, "Alexandru Ioan Cuza" University Press, 2016, p. 191.

55. Barbu Delavrancea, Opere I/ Works 1, p. 154.

56. Emilia Șt. Milicescu, "Introduction” in Barbu Delavrancea, Opere I/ Works 1, p. XXXII.

57. Emilia S,t. Milicescu, Delavrancea, p. 221, 238.

58. Ion Negoițescu, Istoria..., p. 133.

59. Tudor Vianu, "Delavrancea," in Scriitori..., pp. 595-596.

60. Barbu Delavrancea, qtd. in Emilia S,t. Milicescu, Delavrancea, p. 217.

61. Barbu Delavrancea, "Regimul," in Opere VIII/ Works 8, p. 10.

62. Al. Săndulescu, Delavrancea, Bucharest, EPL Publishers, 1964, pp. 37-49.

63. Barbu Delavrancea, "Lumină tuturora," in Opere VIIL Works 8, pp. 203-228.

64. Judith Schlanger, Presence..., pp. 69-99.

65. Barbu Delavrancea, "Discursul dlui Delavrancea rostit in ședința de la 9 decembrie 1894 a Camerei Deputaților," in Oratorie politică românească (1847-1899), vol. 3, pp. 181-194.

66. Barbu Delavrancea, "Regimul," in Opere VIII/ Works 8, pp. 9-57.

67. Barbu Delavrancea, "Discursul dlui Delavrancea rostit in ședința de la 9 decembrie 1894 a Camerei Deputaților," in Oratorie politică românească (1847-1899), vol. 3, p. 196.

68. Barbu Delavrancea, "Discurs rostit în camera deputaților în ședința de la 11 ianuarie 1895, cu prilejul Legii numelui," in Opere VIIL/Works 8, pp. 83-91. 